\title{
NOTE
}

\section{Short-term nutrient pulses as tools to assess responses of coral reef macroalgae to enhanced nutrient availability}

\author{
Britta Schaffelke* \\ Australian Institute of Marine Science, PMB 3, Townsville, MC 4810, Australia \\ Cooperative Research Centre: Reef Research, James Cook University, Townsville 4811, Australia
}

\begin{abstract}
Inshore coral reefs of the Great Barrier Reef, Australia, are subjected to episodic nutrient inputs, mainly by rain and riverine run-off during the summer wet season. Increased nutrient availability, potentially caused by human activity, is assumed to enhance the production of primary producers. To simulate increased nutrient inputs, 6 species of coral reef macroalgae were treated with short-term $(24 \mathrm{~h})$ nutrient pulses of $10 \mu \mathrm{M}$ ammonium and/or $1 \mu \mathrm{M}$ phosphate. Sargassum baccularia, an inshore perennial algae, had a $-50 \%$ higher net photosynthetic rate and $\sim 40 \%$ higher tissue nutrients after nutrient addition. The net photosynthetic rates of the inshore, ephemeral species Chnoospora implexa, Hydroclathrus clathratus, and Padina tenuis increased by $\sim 30$ to $50 \%$ and the tissue nutrient levels by 10 to $20 \%$ after a single nutrient pulse. Two perennial species, Chlorodesmis fastigiata and Turbinaria ornata, which occur inshore as well as on reefs further offshore, did not respond to nutrient addition with higher production, however, accumulated 15 to $20 \%$ more tissue nutrients than untreated thalli. The different responses to nutrient pulses of macroalgal species with different life cycles and distributional ranges provide important information for the prediction of the response of whole inshore reef communities.
\end{abstract}

KEY WORDS: Nutrient pulse - Coral reef macroalgae - Photosynthesis - Tissue nutrients

In contrast to the common perception that macroalgae are rare on coral reefs, inshore areas of the Great Barrier Reef (GBR), Australia, are colonised by a biomass-rich and diverse macroalgal community (Morrissey 1980, Price 1989, Schaffelke \& Klumpp 1997). Increases in macroalgal abundance on coral reefs have been observed during the past 2 decades in Hawaii, Florida, and the Caribbean (Smith et al. 1981, Lapointe 1989, Hughes 1994). Whether similar changes have occurred in the GBR region is not known, because long-term datasets on algal distribution and abun-

·E-mail: b.schaffelke@aims.gov.au dance are not available (discussed in McCook \& Price 1997). Increased nutrient inputs caused by human activity have been regarded as one of the major causes of increased macroalgal abundance on coral reefs (Smith et al. 1981, Pastorok \& Bilyard 1985, Lapointe et al. 1997). Further causes for a shift from high hard coral to high macroalgal abundance are the reduction of herbivores and catastrophic events such as tropical cyclones (Done 1992, Hughes 1994).

An increase in available nutrients in GBR waters over the last 2 decades has been suggested by Bell (1992), but has recently been questioned by Brodie et al. (1997). However, it has been estimated through the use of catchment models that the nutrient discharge by rivers has increased by 4 times since European settlement of the Queensland coast (Neil \& Yu 1996). Nutrients are mainly imported into GBR waters through rain and rivers (Furnas et al. 1995), predominantly as raindriven pulses of nutrients during the wet season in austral summer. The nutrient-rich monsoonal flood plumes inundate the nearshore reefs of the GBR more frequently than the midshelf reefs (Steven et al. 1996). If, as a result of human activity, nutrient inputs into rivers increased, seasonal nutrient pulses during discharge events may be a main nutrient source to sustain the growth of primary producers on nearshore reefs.

The production of a number of species of coral reef macroalgae respond to short-term nutrient pulses (Lapointe 1985, Littler et al. 1991, Delgado \& Lapointe 1994, Schaffelke \& Klumpp 1998a). This may be facilitated by fast short-term uptake rates and subsequent nutrient storage, an adaptation found in temperate macroalgae from habitats with episodic nutrient supply (Chapman \& Craigie 1977, Probyn \& Chapman 1982, Rosenberg et al. 1984, Fujita et al. 1989).

Results from manipulative experiments with a range of species are prerequisites to understand the res- 
ponses of coral reef macroalgal communities to potential increases in nutrient availability. It is important to assess the type and the degree of nutrient-limitation of growth and/or production as indicators for the potential of macroalgae to increase these parameters when more nutrients are available. In this study, the net photosynthesis and respiration rates and the tissue nutrient levels of 6 abundant species of coral reef macroalgae were measured after short-term pulses of nitrogen (N) and/or phosphorus (P). The experimental species have different distributional ranges (inshore/inshore and offshore) and life cycles (perennial/ephemeral).

Materials and methods. Collection of algae: Of the 6 selected species, 4 brown algal species are very common on coastal reefs of the central GBR and virtually absent from reefs further of fshore (McCook et al. 1997. pers. obs.): the perennial species Sargassum baccularia (Mertens) C. Agardh and the ephemerals Chnoospora implexa (Heringar) J. Agardh, Hydroclathrus clathratus (C. Agardh) Howe, and Padina tenuis Bory. C. implexa and $H$. clathratus occur during austral spring. $P$. tenuis occurs throughout the year with abundance maxima during spring and autumn (Schaffelke \& Klumpp 1997); this species can very occasionally be found on reefs further offshore. The other 2 species, the green alga Chlorodesmis fastigiata (C. Agardh) Ducker and the brown algae Turbinaria ornata (Turner) J. Agardh, are perennial and are common on inshore as well as on offshore reefs of the GBR (McCook et al. 1997, pers. obs.). All specimens were collected at -2 to $3 \mathrm{~m}$ depth on the reef flat or reef slope of a fringing coral reef at Orpheus Island, a nearshore continental island in the central GBR $\left(146^{\circ} 30^{\prime} \mathrm{E}, 18^{\circ}\right.$ $\left.37^{\prime} \mathrm{S}\right)$. Thalli were kept for $24 \mathrm{~h}$ in filtered $(10 \mu \mathrm{m})$, flowing seawater in the outdoor aquarium facility of the Orpheus Island Research Station (OIRS) until used.

Photosynthesis and respiration after $24 \mathrm{~h}$ pulse treatments: Each species was treated in a separate experiment, each of which was conducted in 2 experimental runs in the outdoor aquarium facility. Two out of 4 nutrient treatments were randomly assigned to each run. Single thalli ( $1 \mathrm{~g}$ fresh weight) were placed in separate $1 \mathrm{l}$ plastic jars filled with filtered $(0.5 \mu \mathrm{m})$ seawater (ambient nutrient concentrations: $\sim 0.3 \mu \mathrm{M}$ dissolved inorganic nitrogen, $-0.04 \mu \mathrm{M}$ phosphate). Ten replicate jars were left either unfertilised, or were fertilised with reagent-grade ammonium chloride to $10 \mu \mathrm{M}$ ammonium, and/or with sodium-dihdrogenphosphate to $1 \mu \mathrm{M}$ phosphate. Mixing was achieved by aeration. The water was exchanged every $3 \mathrm{~h}$ to avoid significant nutrient depletion. Pilot measurements indicated that after $3 \mathrm{~h}$ the algae had taken up less than $30 \%$ of the initially added nutrients. The pulse jars were shaded to simulate light conditions at $-3 \mathrm{~m}$ depth, and were temperature equilibrated with flowing ambient seawater.
The production measurements of the 20 replicate thalli of each run started immediately after the $24 \mathrm{~h}$ pulses, and were completed after $\sim 14 \mathrm{~h}$. All thalli were transferred to a large tank $(2.0 \times 0.9 \times 0.5 \mathrm{~m})$, supplied with filtered $(0.5 \mu \mathrm{m})$ ambient seawater at a flow rate of $0.5 \mathrm{l} \mathrm{min}^{-1}$ in a temperature controlled room (to maintain the ambient water temperature of $26^{\circ} \mathrm{C}$ ). In this tank, rates of net photosynthesis in artificial light [300 $\mu \mathrm{mol}$ photons $\mathrm{m}^{-2} \mathrm{~s}^{-1}$, an irradiance saturating the photosynthesis of Sargassum baccularia and Padina tenuis, Schaffelke unpubl. data) and dark-respiration of each thallus were each measured for $1 \mathrm{~h} 20 \mathrm{~min}$. Thalli were incubated in the 4 perspex chambers of a data-logging respirometer equipped with oxygen electrodes, with automated flushing of the chambers every 15 min, as in Schaffelke \& Klumpp (1998a). The sequence was randomised in which the thalli were picked for production measurements. Directly after the measurements, thalli were briefly rinsed in freshwater and dried at $60^{\circ} \mathrm{C}$ for $24 \mathrm{~h}$. The net photosynthetic and respiration rates of the replicate thalli were normalised to dry weights.

Tissue nutrients: All thalli from the production measurements were ground with mortar and pestle to a fine powder and stored at $-18^{\circ} \mathrm{C}$. Total $\mathrm{N}$ was determined with an ANTEK C/N analyser. For analysis of total $\mathrm{P}$, ground tissue was combusted for $1 \mathrm{~h}$ at $450^{\circ} \mathrm{C}$, extracted with purified water for $12 \mathrm{~h}$ at $4^{\circ} \mathrm{C}$, and the extract filtered and determined for total phosphorus according to Koroleff (1983).

Statistical analyses: The experiments were analysed with separate 2-way ANOVAs with the factors ' $N$ ' and ' $P$ ' (both in 2 levels, presence or absence) for each dependent variable (net photosynthetic rates, respiration rates, tissue $\mathrm{N}$, and tissue $\mathrm{P}$ ). Data were log- (photosynthesis, respiration) or arcsine- (tissue nutrients) transformed and the homogeneity of variances confirmed with Cochran's test. In case of a non-significant ANOVA result $(p>0.05)$, the detectable-effect size for the main factors were calculated after Cohen (1988) to investigate the power of the analyses

Results. The responses of the macroalgae to the experimental nutrient pulses were species-specific. The mean net photosynthetic rate of Sargassum baccularia increased by $\sim 50 \%$ after $\mathrm{N}$ and $\mathrm{P}$ additions, compared to untreated thalli (Table 1, Fig. 1a). The tissue $\mathrm{N}$ and $\mathrm{P}$ levels were more than $40 \%$ higher after the $\mathrm{N}$ and P pulses, respectively (Table 1, Fig. 2a,b). The net photosynthetic rate of Chnoospora implexa increased by $\sim 30 \%$ after $N$ addition (Table 1 , Fig. 1c). In the other ephemeral species, Hydroclathrus clathratus, both $\mathrm{N}$ and $\mathrm{P}$ addition increased net photosynthetic rate by $\sim 50 \%$ compared to untreated thalli (Fig. 1e). The $\mathrm{N} \times \mathrm{P}$ interaction was significant, indicating that the response to $\mathrm{N}$ addition was dependent on the addition of 
Table 1. Summary of 2-way ANOVAs on the effects of nutrient pulses on net photosynthetic rate, respiration rate, tissue nitrogen, and tissue phosphorus of each of 6 macroalgal species. Factors were ammonium (N) and phosphate (P) addition. Net photosynthesis and respiration data were log-transformed, tissue nutrient data arcsine-transformed. Degrees of freedom of residuals in each $A N O V A=36$. Min $\Delta=$ detectable-effect size for non-significant main effects

\begin{tabular}{|c|c|c|c|c|c|c|c|c|c|}
\hline \multirow[t]{2}{*}{ Species } & \multirow{2}{*}{$\begin{array}{l}\text { Source of } \\
\text { variation }\end{array}$} & \multicolumn{2}{|c|}{ Photosynthesis } & \multicolumn{2}{|r|}{ Respiration } & \multirow[b]{2}{*}{$p$-value } & \multirow{2}{*}{$\begin{array}{c}\text { Tissue } N \\
\text { Min } \Delta\end{array}$} & \multirow{2}{*}{$\begin{array}{l}\text { Tissue } P \\
\mathrm{p} \text {-value }\end{array}$} & \multirow[b]{2}{*}{$\operatorname{Min} \Delta$} \\
\hline & & $\mathrm{p}$-value & $\operatorname{Min} \Delta$ & $p$-value & $\operatorname{Min} \Delta$ & & & & \\
\hline \multirow[t]{3}{*}{ Sargassum baccularia } & $\mathrm{N}$ & 0.0001 & - & 0.403 & $16 \%$ & 0.0001 & - & 0.348 & $10 \%$ \\
\hline & $\mathrm{P}$ & 0.0001 & - & 0.414 & $16 \%$ & 0.448 & $10 \%$ & 0.0001 & - \\
\hline & $\mathrm{N} \times \mathrm{P}$ & 0.482 & & 0.850 & & 0.879 & & 0.414 & \\
\hline \multirow{3}{*}{ Chnoospora implexa } & $\mathrm{N}$ & 0.0001 & - & 0.057 & $13 \%$ & 0.861 & $9 \%$ & 0.254 & $7 \%$ \\
\hline & $\mathrm{P}$ & 0.538 & $14 \%$ & 0.797 & $13 \%$ & 0.140 & $9 \%$ & 0.0001 & - \\
\hline & $\mathrm{N} \times \mathrm{P}$ & 0.666 & & 0.679 & & 0.307 & & 0.324 & \\
\hline \multirow[t]{3}{*}{ Hydroclathrus clathratus } & $S \mathrm{~N}$ & 0.0003 & - & 0.117 & $13 \%$ & 0.029 & - & 0.208 & $7 \%$ \\
\hline & $\mathrm{P}$ & 0.008 & - & 0.413 & $13 \%$ & 0.918 & $13 \%$ & 0.0001 & - \\
\hline & $\mathrm{N} \times \mathrm{P}$ & 0.006 & & 0.821 & & 0.392 & & 0.959 & \\
\hline \multirow[t]{3}{*}{ Padina tenuis } & $\mathrm{N}$ & 0.0001 & - & 0.962 & $13 \%$ & 0.0001 & - & 0.403 & $5 \%$ \\
\hline & $\mathrm{P}$ & 0.0001 & - & 0.135 & $13 \%$ & 0.167 & $7 \%$ & 0.0001 & - \\
\hline & $\mathrm{N} \times \mathrm{P}$ & 0.148 & & 0.122 & & 0.390 & & 0.643 & \\
\hline \multirow[t]{3}{*}{ Turbinaria ornata } & $\mathrm{N}$ & 0.389 & $11 \%$ & 0.929 & $16 \%$ & 0.0001 & - & 0.223 & $9 \%$ \\
\hline & $\mathrm{P}$ & 0.969 & $11 \%$ & 0.250 & $16 \%$ & 0.544 & $12 \%$ & 0.0001 & - \\
\hline & $\mathrm{N} \times \mathrm{P}$ & 0.788 & & 0.920 & & 0.213 & & 0.103 & \\
\hline \multirow[t]{3}{*}{ Chlorodesmis fastigiata } & $\mathrm{N}$ & 0.534 & $12 \%$ & 0.758 & $12 \%$ & 0.0001 & - & 0.392 & $9 \%$ \\
\hline & $\mathrm{P}$ & 0.629 & $12 \%$ & 0.852 & $12 \%$ & 0.592 & $7 \%$ & 0.567 & $9 \%$ \\
\hline & $\mathrm{N} \times \mathrm{P}$ & 0.555 & & 0.575 & & 0.998 & & 0.998 & \\
\hline
\end{tabular}

$\mathrm{P}$ (Table 1). Tissue P of C. implexa increased by $13 \%$ after $\mathrm{P}$ addition, whereas $\mathrm{N}$ addition had no effect on tissue nutrient levels (Table 1, Fig. 2c,d). The tissue nutrients of $H$. clathratus increased by 9 to $18 \%$ after $N$ and $P$ addition, respectively (Table 1, Fig. $2 e, f$ ). The net photosynthetic rate of Padina tenuis increased by
$-30 \%$ after $\mathrm{N}$ and $\mathrm{P}$ pulses (Fig. $1 \mathrm{~g}$ ). Also, tissue $\mathrm{N}$ and $P$ levels were 19 and $11 \%$ higher, after addition of $N$ and $P$, respectively (Table 1 , Fig. $2 g, h$ ).

The net photosynthetic rates of Turbinaria ornata and Chlorodesmis fastigiata did not increase after nutrient pulses (Table 1, Fig. 1i,k). Tissue $\mathrm{N}$ and $\mathrm{P}$ lev-

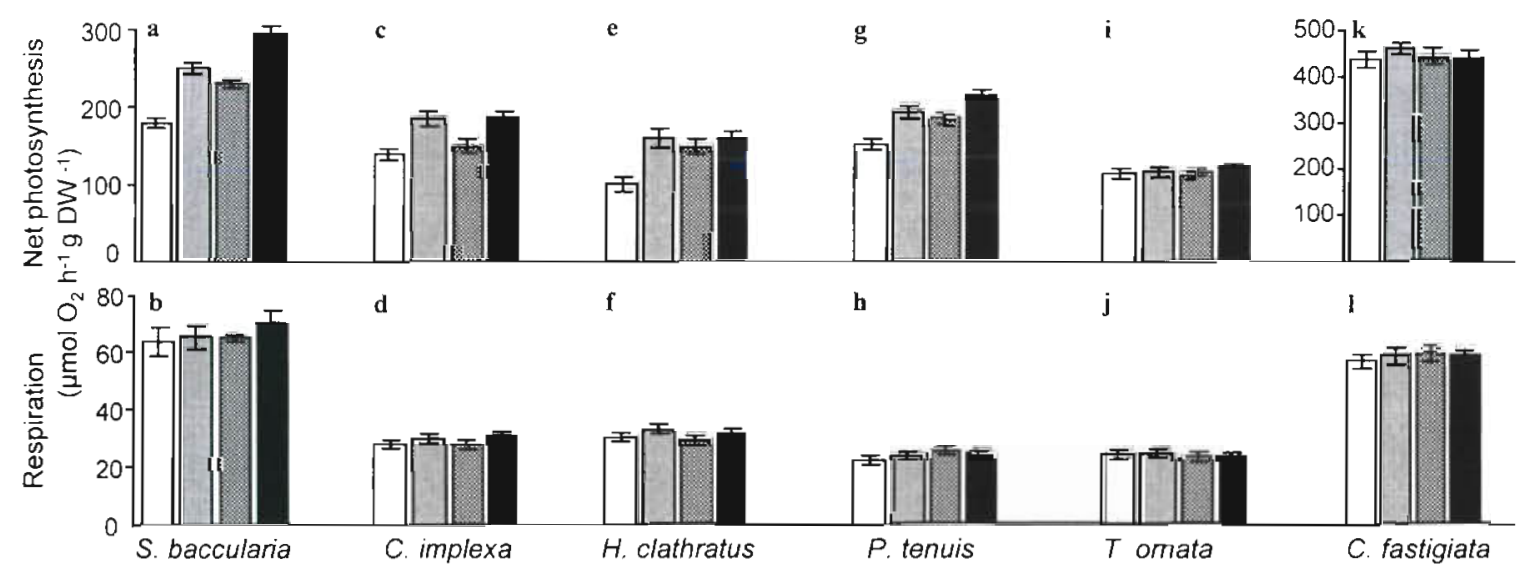

Fig. 1. Net photosynthetic and dark respiration rates of Sargassum baccularia (a, b), Chnoospora implexa (c, d), Hydroclathrus clathratus (e, f), Padina tenuis $(\mathrm{g}, \mathrm{h})$, Turbinaria ornata $(\mathrm{i}, \mathrm{j})$, and Chlorodesmis fastigiata ( $\mathrm{k}, \mathrm{l})$ after a single $24 \mathrm{~h}$ nutrient pulse. Bars represent means of the treatment combinations of the factorial nutrient pulse design: white bars: ambient levels of ammonium $(\mathrm{N})$ and phosphate $(\mathrm{P})$; light grey bars: $10 \mu \mathrm{M} \mathrm{N}$ and ambient $\mathrm{P}$; dark grey bars: ambient $\mathrm{N}$ and $1 \mu \mathrm{M} \mathrm{P}$; black bars: $10 \mu \mathrm{M}$ $\mathrm{N}$ and $1 \mu \mathrm{M}$ P. Error bars are 1 standard error $(\mathrm{n}=10)$ 


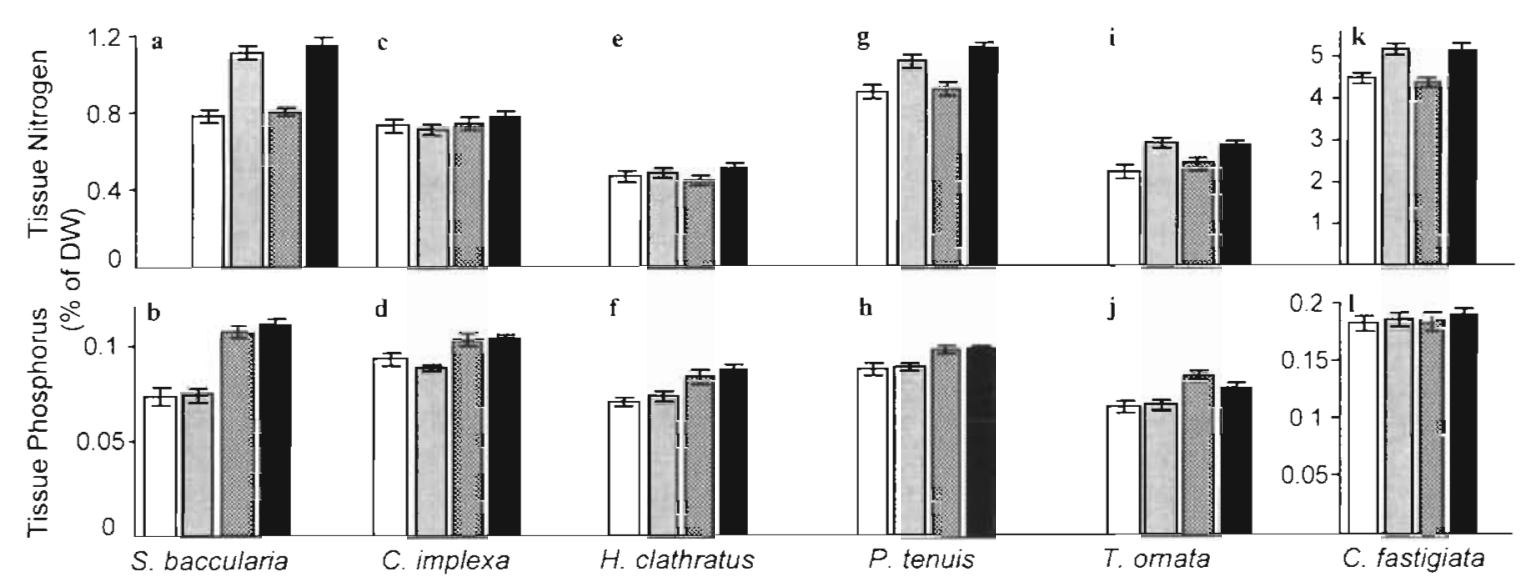

Fig. 2. Tissue nitrogen and phosphorus levels of Sargassum baccularia (a, b), Chnoospora implexa (c, d), Hydroclathrus clathratus $(e, f)$, Padina tenuis $(g, h)$, Turbinaria ornata $(i, j)$, and Chlorodesmis fastigiata $(k, l)$ after a single 24 h nutrient pulse. Other details as in Fig. 1

els of $T$. ornata increased 23 and $18 \%$, respectively, after $\mathrm{N}$ and $\mathrm{P}$ addition (Table 1, Fig. $2 \mathrm{i}, \mathrm{j}$ ). Tissue $\mathrm{N}$ of $\mathrm{C}$. fastigiata was significantly higher in $\mathrm{N}$-treated thalli; tissue $P$, however, was not different between treatments (Table 1, Fig. $2 \mathrm{k}, \mathrm{l}$ ). The dark respiration rates of the 6 species did not respond to a nutrient addition (Table 1, Fig. $1 b, d, f, h, j, l$ ). For the main effects that gave no significant responses after nutrient pulses, the calculated detectable-effect sizes were between 5 and $16 \%$ (Table 1).

Discussion. The experiments presented in this note simulated the effects of pulses of enhanced nutrients on the production and the tissue nutrient levels of 6 coral reef macroalgal species. The 4 species that occur almost exclusively on inshore reefs (Sargassum baccularia, Chnoospora implexa, Hydroclathrus clathratus, Padina tenuis; McCook et al. 1997, pers. obs.) showed production increases of at least $30 \%$ after a single nutrient pulse, indicating nutrient-limitation of production. In contrast, the production of the 2 species with a cross-shelf distribution (Chlorodesmis fastigiata, Turbinania ornata) did not respond to a nutrient addition, which indicates that these species were nutrientsufficient in the experimental conditions.

The capacity to utilise stored nutrients to sustain growth over a prolonged period of time when nutrient availability is low has been recognised as a strategy of macroalgae in environments with episodic pulses of elevated nutrients (Rosenberg et al. 1984, Fujita et al. 1989). In the present study, the nutrient additions resulted in all cases in enhanced tissue nutrient levels. Specimens of the perennial inshore species Sargassum baccularia had $\sim 40 \%$ higher tissue nutrient levels after the nutrient pulses. The tissue nutrient levels of the other species increased by between 9 and $23 \%$ Although the ephemeral species, Chnoospora implexa,
Hydroclathrus clathratus, and Padina tenuis responded to higher nutrient availability with a production increase, they accumulated much less tissue nutrients than $S$. baccularia. This indicates that they have used most of the available nutrients directly for production and may be regarded as opportunistic species. The production of the perennial species with a crossshelf distribution (Chlorodesmis fastigiata, Turbinaria ornata) was not nutrient-limited in this study, and the enhanced tissue nutrient levels indicate that surplus available nutrients were stored. The species-specific differences in tissue nutrient accumulation suggest that the use of tissue nutrient levels as indicators of nutrient availability is limited and only meaningful in conjunction with production or growth measurements.

The conclusions drawn from the non-significant results are not that there were no effects of nutrient pulses, but that the differences between treatment means were smaller than the detectable-effect size. With 36 degrees of freedom in the error, I believe that the experimental design was suitable to detect ecologically meaningful responses to nutrient additions. This is also indicated by the calculated detectable-effect size for the non-significant main effects that was in all cases $<16 \%$. The nutrient pulse design was based upon a detailed study applying nutrient pulses in different concentrations, durations, and frequencies (Schaffelke \& Klumpp 1998a). To obtain a first overview of the type and range of macroalgal responses, experimental nutrient pulses are very useful as they circumvent the problems associated with in situ nutrient enhancement experiments, such as variable background nutrient levels, and the loss of added nutrients by tidal flushing or by nutrient uptake by other reef biota (Hatcher \& Larkum 1983, A. Steven pers. comm) 
Lapointe et al. (1993, 1997) and Bell (1992) suggested nutrient threshold values for coral reefs of $1 \mu \mathrm{M}$ dissolved inorganic nitrogen (DIN) and $0.1 \mu \mathrm{M}$ phosphate. Macroalgal blooms have been observed when these concentrations have been exceeded. Water column nutrients in the GBR lagoon are generally low (Furnas et al. 1995) and average water column nutrient concentrations at inshore reef sites were $\sim 0.3 \mu \mathrm{M}$ DIN and $0.02 \mu \mathrm{M}$ phosphate (Schaffelke \& Klumpp 1998b). However, episodically higher nutrient concentrations have been observed at different reef locations (Hatcher \& Hatcher 1981, Crossland \& Barnes 1983, Staunton Smith \& Johnson 1995). The import of nutrients into the GBR region predominantly occurs via riverine discharge-events during the summer monsoonal wet season (Furnas et al. 1995). Flood plumes occasionally inundate the inshore fringing reefs for several days and may have nutrient concentrations in the magnitude of the nutrient pulses used in the present study (Steven et al. 1996). The potential significance of these floods for macroalgae was addressed in an experimental study where a single $24 \mathrm{~h}$ nutrient pulse sustained the growth of a Sargassum species in situ for 2 wk (Schaffelke \& Klumpp 1998a).

Several authors have reported $\mathrm{N}$ - and/or P-limited growth or production of coral reef algae (e.g. Hatcher \& Larkum 1983, Lapointe 1989, Lapointe \& O'Connell 1989, Littler et al. 1991, Delgado \& Lapointe 1994, Larned \& Stimson 1996). The growth and production of GBR Sargassum baccularia is both $\mathrm{N}$ - and P-limited and has been enhanced by $\mathrm{N}$ and $\mathrm{P}$ addition; the maximal response was achieved with both elements supplied together, and with low initial tissue nutrients (Schaffelke \& Klumpp 1998a,b). Should the nutrient availability increase in the future, e.g. caused by human activity, those coral reef macroalgae that are now recognised as being nutrient-limited may have the potential for increased growth. This may lead to increased macroalgal biomass, when other factors such as substrate availability and grazing pressure allow so.

The present study reports only a 'snap-shot' assessment for the season when both ephemeral and perennial species occur. The results, however, indicate important species-specific differences. The element, $\mathrm{N}$ and/or $\mathrm{P}$, which triggered a response differed between species, as did the magnitude of the response. Species with a predominantly inshore distribution show more pronounced responses than the typical coral reef species with a larger distributional range. In the long term, increased nutrients may hence lead to a shift in macroalgal species composition. To predict the extent of a nutrient-mediated production stimulation on the scale of a whole coral reef community, the competition for nutrients between macroalgae and other primary producers (i. e. phytoplankton, microphytobenthos, and symbiotic algae) needs to be evaluated, as well as their interactions with other reef biota, e.g consumers of photoautotrophic biomass.

Acknowledgements. Thanks are due to the staff of Orpheus Island Research Station, who made my stay enjoyable and successful, and to D. W. Klumpp for the use of the respirometer. S. Uthicke has been an invaluable help during the experiments and his comments greatly improved the manuscript The constructive criticism of the 3 anonymous reviewers is gratefully acknowledged. This is AIMS contribution No. 955

\section{LITERATURE CITED}

Bell PRF (1992) Eutrophication and coral reefs - some examples in the Great Barrier Reef lagoon. Wat Res 26:553-568

Brodie JE, Furnas MJ, Steven ADL, Trott LA, Pantus F, Wright M (1997) Monitoring chlorophyll in the Great Barrier Reef lagoon: trends and variability. Proc 8th Coral Reef Symp 1: $797-802$

Chapman ARO, Craigie JS (1977) Seasonal growth in Laminaria longicruris: relations with dissolved inorganic nutrients and internal reserves of nitrogen. Mar Biol 40:197-205

Cohen J (1988) Statistical power analysis for the behavioural sciences. Lawrence Erlbaum Associates, Hillsdale, NJ

Crossland CJ, Barnes DJ (1983) Dissolved nutrients and organic particulates in water flowing over coral reefs at Lizard Island. Aust J Mar Freshw Res 34:835-844

Delgado O, Lapointe BE (1994) Nutrient-limited production of calcareous versus fleshy macroalgae in a eutrophic, carbonate-rich tropical marine environment. Coral Reefs 13: $151-159$

Done TJ (1992) Phase shifts in coral communities and their ecological significance. Hydrobiologia 247:121-132

Fujita RM, Wheeler PA, Edwards RL (1989) Assessment of macroalgal nutrient limitation in a seasonal upwelling region. Mar Ecol Prog Ser 53:293-303

Furnas MJ, Mitchell AW, Skuza M (1995) Nitrogen and phosphorus budget for the Central Great Barrier Reef Shelf. Research Publication No. 36, Great Barrier Reef Marine Park Authority, Townsville, p 1-194

Hatcher AI, Hatcher BG (1981) Seasonal and spatial variation in dissolved inorganic nitrogen in One Tree Island lagoon. Proc 4th Int Coral Reef Symp 1:419-424

Hatcher BG, Larkum AWD (1983) An experimental analysis of factors controlling the standing crop of the epilithical algal community on a coral reef. J Exp Mar Biol Ecol 69:61-84

Hughes TP (1994) Catastrophes, phase-shifts and large scale degradation of a Caribbean coral reef. Science 265: $1547-1551$

Koroleff $F$ (1983): Determination of total phosphorus by acid persulphate oxidation. In: Grasshoft $K$, Ehrhardt $M$, Kremling $\mathrm{K}$ (eds) Methods of seawater analyses. Verlag Chemie, Weinheim, p 134-136

Lapointe BE (1985): Strategies for pulsed nutrient supply to Gracilaria cultures in the Florida Keys: interactions between concentration and frequency of nutrient pulses. J Exp Mar Biol Ecol 93:211-222

Lapointe BE (1989) Macroalgal production and nutrient relations in oligotrophic areas of Florida Bay. Bull Mar Sci 44: $312-323$

Lapointe BE, O'Connell J (1989) Nutrient-enhanced growth of Cladophora prolifera in Harrington Sound, Bermuda eutrophication of a confined phosphorus-limited marine ecosystem. Estuar Coast Shelf Sci 28:347-360 
Lapointe BE, Littler MM, Littler DS (1993) Modification of benthic community structure by natural eutrophication: the Belize Barrier Reef. Proc 7 th Int Coral Reef Symp 1. $323-334$

Lapointe BE, Littler MM, Littler DS (1997) Macroalgal overgrowth of fringing coral reefs at Discovery Bay, Jamaica: bottom-up versus top-down control. Proc 8th Coral Reef Symp 1:927-932

Larned ST, Stimson J (1996) Nitrogen-limited growth in the coral reef chlorophyte Dictyosphaeria cavernosa, and the effect of exposure to sediment-derived nitrogen on growth. Mar Ecol Prog Ser 145: 95-108

Littler MM, Littler DS, Titlyanov EA (1991) Comparisons of Nand P-limited productivity between high granitic islands versus low carbonate atolls in the Seychelles Archipelago: a test of the relative-dominance paradigm. Coral Reefs 10: 199-209

McCook LJ, Price IR (1997) Macroalgal distributions on the Great Barrier Reef: a review of patterns and causes. The Great Barrier Reef, science, use and management: a national conference. Proceedings, Vol 2. Great Barrier Reef Marine Park Authority, Townsville, p 37-46

McCook LJ, Price IR, Klumpp DW (1997) Macroalgae on the GBR: causes or consequences, indicators or models of reef degradation. Proc 8th Int Coral Reef Symp 2:1851-1856

Morrissey J (1980) Community structure and zonation of macroalgae and hermatypic corals on a fringing reef flat of Magnetic Island Queensiand, Australia. Aquat Bot 8:91-139

Neil DT, Yu B (1996) Fluvial sediment yield to the Great Barrier Reef Lagoon: spatial patterns and the effect of land use. In: Hunter HM, Eyles AG, Rayment GE (eds) Downstream effects of land use. Department of Natural Resources, Queensland, p 281-286

Pastorok RA, Bilyard GB (1985) Effects of sewage pollution on coral-reef communities. Mar Ecol Prog Ser 21:175-189

Editorial responsibility: Otto Kinne (Editor),

Oldendorf/Luhe, Germany
Price IR (1989) Seaweed phenology in a tropical Australian locality (Townsville, North Queensland). Bot Mar 32: $399-406$

Probyn TA, Chapman ARO (1982) Nitrogen uptake characteristics of Chordaria flagelliformis (Phaeophyta) in batch mode and continuous mode experiments. Mar Biol 71: $129-133$

Rosenberg G, Probyn TA, Mann KH (1984) Nutrient uptake and growth kinetics in brown seaweeds: response to continuous and single additions of ammonium. J Exp Mar Biol Ecol 80:125-146

Schaffelke B, Klumpp DW (1997) Biomass and productivity of tropical macroalgae on three nearshore fringing reefs in the central Great Barrier Reef, Australia. Bot Mar 40: $373-383$

Schaffelke B, Klumpp DW (1998a) Short-term nutrient pulses enhance growth and photosynthesis of the coral reef macroalga Sargassum baccularia. Mar Ecol Prog Ser 170: 95-105

Schaffelke B, Klumpp DW (1998b) Nutrient-limited growth of the coral reef macroalga Sargassum baccularia and experimental growth enhancement by nutrient addition in continuous flow culture. Mar Ecol Prog Ser 164:199-211

Smith SV, Kimmerer WJ, Laws EA, Brock RE, Walsh TW (1981) Kaneohe Bay sewage diversion experiment: perspectives on ecosystem responses to nutritional perturbation. Pacific Science 35:84-92

Staunton Smith J, Johnson CR (1995) Nutrient inputs from seabirds and humans on a populated coral cay. Mar Ecol Prog Ser 124:189-200

Steven A, Devlin M, Brodie J, Baer M, Lourey M (1996) Spatial influence and composition of river plumes in the central Great Barrier Reef. In: Hunter HM, Eyles AG, Rayment GE (eds) Downstream effects of land use. Department of Natural Resources, Queensland, p 85-92

Submitted: July 10, 1998; Accepted: December 9, 1998 Proofs received from author(s): May 6, 1999 